\title{
CONSCIOUSNESS AS A CENTRAL PROBLEM OF MODERN PSYCHOLOGY
}

\author{
Garnik V. Akopov \\ Samara State Pedagogical University \\ Samara
}

\begin{abstract}
The special status of the theme of consciousness in modern science is caused by a number of circumstances: considerable growth of scientific papers in the last quarter of XX and the beginning of XXI centuries, transition of modern society from the postindustrial phase to the informative, and also by the newest philosophy, new scientific ideology, ideas of postmodernism, etc.; there appeared such new integrated fields of knowledge as neuroscience, cognitive science, science of consciousness.
\end{abstract}

Keywords: modern psychology, consciousness, science, ideology.

The special status of the theme of consciousness in modern science is caused by a number of circumstances. The first of them is a considerable growth of scientific papers in the last quarter of XX and the beginning of XXI centuries. The new surge of scientific interest to the consciousness problem, considerably surpassing all the previous, may be explained mainly by the transition of modern society from the postindustrial phase to the informative, and also by the newest philosophy, new scientific ideology, ideas of postmodernism, etc.; there appeared such new integrated fields of knowledge as neuroscience, cognitive science, science of consciousness. In practice one can see a more active and purposeful intervention of a man to the processes of the physical, biological and social world and not always distinct comprehension of the long-term consequences of such intervention.

Another prominent feature of the problem of consciousness is the impossibility of reference of this theme only to one particular area of science or to one psychological direction since consciousness including human thinking is included to every sphere of human activity. In psychology particularly consciousness is represented in all psychological schools and guidelines from behaviorism with its negation of consciousness to humanistic psychology with its highly utilitarian attitude to consciousness. 
Foreign studies on the consciousness problem can be regarded as a continuum, starting from neuroscientific approaches to mechanisms and functions of consciousnesses to cognitive approaches in the description of consciousness functioning types. The attempts to study consciousness by means of physical variables (quantum, wave and molecular mechanisms) and computer programs on artificial intelligence adjoin the margins of this continuum. In explanatory schemes of foreign authors an extreme biologism (Searle, 1997; 2000) as well as systematic substantialism (Chalmers, 1996; 1997) can be seen. In general, the modern space of consciousness studies can be represented in two dimensions: the "continuum" of unitary-interdisciplinary researches, with its extremes of phenomenalism (introspection) and phisicalism; and a value-utilitarian dimension with extremes of mystical spirituality and manipulation, this may also correspond to the positions of teleologism (pre-established harmony) and social constructionism.

High theoretical engagement and insignificant demand of consciousness in applied works may not be casual for the existing system of psychological knowledge and practice. Moreover, in a number of new directions of Russian psychology consciousness "works" not only as a basic category, but also as a distinct operational concept. In particular, such new trends are: the psychosemantic concept of consciousness developed by V.F. Petrenko both in theoretical and in highly applicable aspects; psychologics of consciousness as a new general basis of psychology developed by the scientific school under the guidance of V.M. Allakhverdov; vast series of research by V.V. Znakov on the psychology of understanding and self-understanding as the major display of human consciousness and life; V.A. Labunskaya's new studies on realised and non-realised components of nonverbal expression of a person; A.O. Prokhorov's unique researches on the problem of semantic determination of mental conditions; historic and psychological as well as paradigmatic approaches by V.A. Shkuratov, particularly, to the problem of connection between the dissociation of a person and consciousness genesis; E.A. Sergienko's cognitive platform of consciousness study in early ontogenesis of a person; V.E. Semenov's original concept of polymental types of consciousness in modern society, etc. It is clear from the list above, that in most cases theoretic and applied researches develop successfully, when not all the consciousness categories but only their certain aspect is mentioned, be it psychosemantic turn, cognitive turn, etc. More universal theoretical schemes of consciousness (structural approaches of A.N. Leontiev, V.P. Zinchenko, A.G. Asmolov, F.E. Vasiljuk) are implemented in practice less, unlike the particular variants 
(psychosemantics of consciousness, the psychologics of consciousness, polymentality of consciousness, etc.). The universal structures, such as the existential and reflective layers of consciousness, biodynamic and sensual fabrics, meaning and sense, "serve" the concept of consciousnesses itself, rather than its practical usage. Moreover, inside the consciousness one can realize only the purpose of consciousness, but not the mechanism of comprehension.

"The new intention" defined as well the search for a new method in research analysis and construction of integral knowledge, that is, a method defined by the subject - con-sciousness, understood as co-awareness, or a method that makes basis to any knowledge, presented in the form of scientific search, in its retro-, actual and transspective projections (Klochko, 2008). Meaningful dialogue is possible notwithstanding the lack of transparency in "conceptual partitions". At the same time V.E. Klochko's statement about the "diffusion of the commonly divided context", which provides the interaction of concepts and acts as "a condition of intra-scientific communication" is fair. In this respect it is important not to lose the common language of communication, that is, a mutually developed and time tested scientific conceptual framework. Today, during the post-non-classical period, on the foreground there is neither absolutization (authoritative knowledge), nor convention of knowledge (the coordinated thinking), but the consolidation of efforts on free realized (reflective) choice of the regulations for search and the corresponding discourse. And if there is a response (a contact), than the relevant communication with perspective of development into scientifically-semantic dialogue and metacommunication on various researches is possible. The context of co-awareness, i.e. joint knowledge, knowledge divided/united by someone is especially important in this case. Therefore, any statement of the carrier of consciousness "armed" with scientific experience about consciousness is valuable and significant. The comparison and forming of a limited set of judgments, opinions, evaluations and statements of a great number of experienced researchers is at the center of the method, as well as scientific contacts and communication that confirm to an extent the freedom of thinking in the forms of realized choice and creative work. Such a construction can be considered as a "communicative methodology" (Mazilov, 2003), or a special genre - a version of the qualitative methods similar to a particular narrative type (the scientific text) with parallel or subsequent meta-narrative analysis. Certainly, every statement has a contextual, genealogical, logical, axiological or personal bases. Therefore, in such an original "puzzle-design" or intentionally regulated assemblage, besides other meta-narrative bases, 
the chronotopical compatibility of the "collected" texts (topological correlation of texts, mental foreseeing or returning to sources from actual time) is essentially important.

It is known, that one of the main features of classical thinking is the use of binary oppositions; logic dichotomies are "the characteristic of the rational classical thinking" (Asmolov, 2002). And it is often met in definitions of consciousness: dialogue and generalization (a systematic and semantic structure of consciousness) by L.S. Vygotstkiy; knowledge and relation by S.L. Rubinshtejn; meaning and sense by A.N. Leontiev; the nonverbal and the semantic in V.F. Petrenko's concept; logic and paradox by V.M. Allakhverdov; remembering and understanding by A.J. Agafonov, etc. Taking into account the all-mighty initial binary division of all the real (finally, a binary code is at the heart of progress and "incomprehensible efficiency" of information technologies), at the same time heterogeneity and variety of bases for various dichotomies is to be noticed. In particular, these are the binaries showing the content of consciousness or its structure and layers, initial condition or result, condition or process, sources (conditions) or factors, etc. Is it possible to speak about any rational choice of the bases and about their possible number? Another feature is that the opposed members of dichotomies are not quite oppositional, and do not connect logic or even dialectic contrasts. But whether there is any advantage of multiplication of dichotomies, or they are exclusively an axiological basis of possibility (freedom) of thinking and, hence, "existing". Apparently, there is logic in the freedom of mental opposition, and that is the logic of the search for the bases or, in other words, the basic knowledge. One of such "root" dichotomies, obviously, is the opposition of "I" - "Another", basically found in L.S. Vygotskiy's cultural-historical psychology, the distinct contours of which become the stronger the more we "hide" behind a virtual screen, trying, in search of adherents, to separate ourselves from the divided consciousness of the two and many. Starting from this opposition fundamental for filo- and ontogenesis one can understand why Vygotskiy spoke about dialogue and generalization as initial acts defining the consciousness; Rubinstain spoke about knowledge and relation (including the relation of another to this knowledge that is the relation through another), etc. It is possible to assume, that intuition, or M.Buber's revelation, was prepared by the "shoulders of giants", and personal character (personal knowledge) of basic dichotomy content expression (form) is not excluded. In this respect consciousness and, accordingly, any theory of consciousness, cannot be unique, as well as universal; initial or final; complete or consistent 
(Akopov, 2008). Another root dichotomy directly connected to the first one, is the opposition of the association-division, attentively investigated by V.I. Molchanov in a variant: distinction - synthesis (identification) (Molchanov, 1992). The link between the chosen oppositions ("I" - "Another", Association-Division) defines, in our opinion, all the variety of the real and the conceivable in the widest range of their displays.

Modern discussions on methodology in Russian psychology and some solutions, such as polyphony, methodological pluralism and liberalism, etc., have not still found the universally recognized form on account of the necessity to subsequently and fundamentally reorganize the whole system of psychological knowledge. In this respect the communicative methodology can be considered the most suitable for defining the principles of establishing interconnections and correlations between various psychological platforms in the process of unbiassed scientific communication, direct or mediated in its character, be it traditional monism or modern liberalism.

The communicative methodology, in our opinion, is more processive and less resulting in its character. The last is mainly presented in the methodology of consolidated knowledge. Using the fixed term "forming" in relation to the structure of consciousness (A.N. Leontiev, V.P. Zinchenko), besides the settled link of meaning and sense (later - existential and reflexive consciousness layers), expressing systematic and semantic structure of consciousness, another Vygotskiy's formula of dialogue and generalization can also be quite efficient.

Probably, here is the "corner stone» which was noticed neither by the opponents nor by the followers. It is also necessary to notice, that the dialogue, though immanently and often implicitly participating in scientific research, knowledge, experimental training, etc., is not always included in the planned, registered (i.e. considered) variables. In any case, the psychological sense of the last link (dialogue and generalization) is more transparent for consciousness "structure", than the term "semantics" with its burden of linguistic connotations or synonymous to consciousness and vaguely interpreted category of sense. Unfortunately, partly voluntarily, partly administratively an established convention for a long time refused to consider dialogue as a category directly and appreciably defining consciousness. It is necessary to note significant efforts of some well-known researchers in this area (A.A. Bodalev, V.A. Labunskaja, A.A. Leontiev, B.F. Lomov, V.N. Miasischev, V.N. Panferov, B.D. Parygin, V.V. Rubtsov, V.E. Semenov, etc.). However, the basic character of dialogue for institutionalization of the consciousnesses of a person (an in- 
dividual, a subject, an individuality) is not fully described in these works. In some A.G. Asmolov's works and, in particular, in F.E. Vasiljuk's works, who had studied the structural forming of consciousnesses before in the context of conventional discourse and who contributed a lot to the development of the idea of forming consciousness (after A.N. Leontiev and V.P. Zinchenko), the dialogue along with activity, setting and relation forms the basic category of Russian psychology.

The scientific consciousness as a dialogue (interpersonal or internal dialogue, reflexion of the scientist) and generalization can also be subject to the influence of setting, i.e. the general, obvious or implicit arrangement, and can be realized in conventional methodology of scientific activity, proclaiming some principles and rejecting other. In our opinion, consolidating methodology can be additional to the conventional one. The consolidation discourse of Russian psychologists contribution to the consciousness problem represents the new type of knowledge and relation. The designed concept: activity-dialogue, setting-relation, perfectly allows to unite theoretical and experimental-applied researches of Russian psychologists of different schools and periods.

In this respect (consolidation intent) the category of dialogue gets the same universal character, as the consciousness itself, since the procedure of dialogue (A.V. Brushlinskiy) is sought both by human life and its understanding (V.V. Znakov), and by scientific knowledge in the forms of the individual and group subject (A.L. Zhuravlyov). In such a dialogue, integrating ontological and gnoseological plans of consciousness, the existential and substantial characteristics of communications and metacommunications can be globally revealed as the reflective layers of stratification. The last can act as an individual/personal display or axiological quality of group consciousness.

\section{References} burg.

Agafonov, A.J. (2003). Bases of the semantic theory of consciousness. St.-Peters-

Akopov, G.V. (2010). Psihologiya soznaniya . Voprosy metodologii, tyeorii i prikladnyh issledovanij [Psychology of Consciousness. Issues of Methodology, Theory and Applied Research]. Moscow: Institute of Psychology of the Russian Academy of Sciences.

Allakhverdov, V.M (2003). Metodologicheskoe puteshestvie po okyeanu bessoznatelnogo $k$ tainstvennomu ostrovu soznaniya [Methodological travel on the ocean of the unconscious to the mysterious island of the consciousness]. St. Petersburg: Rech. 
Asmolov, A.G. (2002). Drugaya storona soznaniya: metodologicheskie problemy neklassicheskoi psihologii [Another side of consciousness: methodological problems of nonclassical psychology]. Moscow: Smysl.

Baars, B.J. (1997). In the Theater of Consciousness: The Workspace of the Mind. NY: Oxford UP.

Bakhtin, M.M (1994). Problemy tvorchestva Dostoevskogo [Problems of creativity of Dostoevsky]. Kiev.

Block, N., Flanagan, O., \& Güzeldere, G. (Eds). (1997). The Nature of Consciousness. Cambridge, MA: MIT Press.

Bodalev, A.A. (1970). Kontseptsii drugogo cheloveka kak individual'nosti [Concepts of other person as individuality]. Leningrad.

Brushlinsky, A.B. (1999). Kontseptsiya predmetnoij dyeyatel'nosti i tyeorii funktsional'nyh system [The concept of subject activity and the theory of functional systems]. Voprosy psikhologii, 5, 110-121.

Buber, M. (1993). Ya i Ty [I and You]. Moscow.

Karpov, A.B. (2007). Problema soznaniya metasistemoticheskogo podhoda. Konferentsiya "Psihologiya soznaniya: sovremennoe sostoyanie i perspektivy" [A problem of consciousness of the metasystematic approach. Conference "Consciousness Psychology: a modern condition and prospects"] (pp. 48-61). Samara.

Chalmers, D.J. (1995). Facing up to the problem of consciousness. The Journal of Consciousness Studies, 2(3), 200-219.

Chalmers, D.J. (1996). The Conscious Mind: In Search of a Fundamental Theory. Oxford and New York: Oxford: Oxford University Press.

Chalmers, D.J. (1997). Moving forward on the problem of consciousness. The Journal of Consciousness Studies, 4(1), 3-46.

Davies, M., \& Humphreys, G. (Eds.). (1993). Consciousness: Psychological and Philosophical Essays. Oxford: Blackwell.

Dennett, D.C. (1996). Facing backwards on the problem of consciousness. The Journal of Consciousness Studies, 3(1), 4-6.

Ey, H. (1983). La conscience. Paris: Desclee de brouwer.

Flanagan, O. (1992). Consciousness Reconsidered. Cambridge, MA: Bradford; London: MIT Press.

Güzeldere, G. (1995). Problems of consciousness: a perspective on contemporary issues, current debates. The Journal of Consciousness Studies, 2(2), 112-143.

Jurevich, A.V. (2005). Psikhologiya i metodologya [Psychology and methodology]. Moscow.

Klochko, V.E. (2008). Postneklassicheskaya nauka i problema ob'yasneniya v psihologii [A postnonclassical science and an explanation problem in psychology]. Metodologija $i$ istorija psihologii, 3(1), 165-178. 
Labunskaja, V.A. (1999). Vyrazhenie litsa: dialog i mezhlichnostnoe znanie [An expression of the person: dialogue and interpersonal knowledge]. Rostov-on-Don.

Leontiev, A.N. (1975). Deyatel'nost', soznanie, lichnost' [Activity, consciousness, person]. Moscow.

Leontiev, A.A. (1997). Psihologija obschenija [Dialogue psychology]. Moscow.

Lomov, B.F. (1979). Kategorii dialoga i dyeyatel'nosti v psikhologii [Categories of dialogue and activity in psychology]. Voprosy psikhologii, 6, 34-47.

Lowe, E.J. (1995). There are no easy problems of consciousness. The Journal of Consciousness Studies, 2(3), 266-271.

Mazilov, V.A. (2003). Metodologiya psikhologicheskoj nauki [Methodology of psychological science]. Yaroslavl'.

Mjasishchev, V.N. (1966). Soznanie kak yedinstvo otrazheniya dyejstvitel'nosti i otnosheniij k nyeij cheloveka [Consciousness as the unity of reality reflexion and man's relation to it]. In Problemy soznaniya: Materialy simpoziuma [Consciousness problems: symposium Materials] (pp. 126-132). Moscow.

Molchanov, V.I. (1992). Paradigmy struktury soznaniya i opyta [Paradigms of consciousness and experience structure]. Logos, 3, 7-36.

Panferov, V.N. (2002). Psikhlogia cheloveka [Psychology of the person]. St.-Petersburg.

Parygin, B.D. (1978). Nauchno-tekhnicheskaya revolutzya i lichnost' [Scientific and technical revolution and the person. Social-psychological problems]. Moscow.

Petrenko, V.F. (2005). Osnovy psikhosemantiki [Fundamentals of Psychosemantics]. St.-Petersburg.

Prohorov, A.O. (2005). Samoregulyatsii psihicheskih sostoyanij: fenomenologiya, mehanizmy, zakony [Self-control of mental conditions: phenomenology, mechanisms, laws]. Moscow.

Rubinshtejn, S.L. (1946). Osnovy obshchyeij psihologii [Fundamentals of general psychology]. Moscow.

Rubtsov, V.V. (1996). Osnovy sotsial'no-geneticheskoij psikhologii [Fundamentals of social-genetic psychology]. Moscow.

Searle, J.R. (1997). The Mystery of Consciousness. London: Granta Books.

Searle, J.R. (2000). Consciousness. In Intellectica, 31, 85-110.

Semenov, V.E. (2005). Sovremennaya russkaya polimental'nost' i psikhicheskie tipi molodezhi [Modern Russian polymentality and mental types of youth]. In Mentalitet russkoij provintsii [Mentality of the Russian province] (pp. 159-163). Samara.

Sergienko, E.A. (2006). Rannee kognitivnoe razvitie: novuj vzglyad [Early cognitive development: the new approach]. Moscow.

Shear, J. (1996). The hard problem: Closing the empirical gap. Journal of Consciousness Studies, 3(1), 54-68. 
Shkuratov, V.A.(1997). Istoricheskayapsikhologiya [Historical psychology].Moscow.

Tassi, P., \& Muzet, A. (2001). Defining the states of consciousness. Neiroscience and Biobehavioral Reviews, 25, 175-191.

Vasiljuk, F.E. (1993). Struktura obraza [Structure of an image]. Voprosy psikhologii, 5, 5-19.

Velmans, M. (2000). Understanding consciousness. London: Routledge.

Vygotsky, L.S. (1982). Soznanie kak problema psikhologii povedeniya [Consciousness as a problem in the Psychology of Behavior. In L.S. Vygotsky. Sobranie sochineniy, t. 3 [Collected works, vol. 3]: Problemi teorii i istorii psihologii [Problems of the Theory and History of Psychology]. Moscow: Pedagogika.

Wilber, K. (1997). An integral theory of consciousness. Journal of Consciousness Studies, 4(1), 71-92.

Zeman, A. (2001). The paradox of consciousness. Lanset, 357 (Issue 9249), p. 77.

Zhuravlyov, A.L. (1983). Sotsial'no-psikhologicheskie problemy upravleniya [Social-psychological problems of management]. In Prikladnye problemy sotsial'noy psikhologii [Applied problems of social psychology] (pp. 173-189). Moscow.

Zinchenko, V.P. (2006). Soznanie kak predmet i delo psikhologii [Consciousness as a subject of psychology]. Metodologiya i istoriya psikhologii, 1(1), 207-231.

Znakov, V.V. (2007). Soznanie, samosoznanie i ponimanie zhizni [Consciousness, self-understanding and life understanding]. Metodologiya $i$ istoriya psikhologii, 2(3), 65-74. 